Article

\title{
Energy Pathways for Future Norwegian Residential Building Areas ${ }^{\dagger}$
}

\author{
Natasa Nord ${ }^{1, * \mathbb{D}}$, Yiyu Ding ${ }^{1}$, Ola Skrautvol ${ }^{2}$ and Stian Fossmo Eliassen ${ }^{3}$ \\ 1 Department of Energy and Process Engineering, Norwegian University of Science and Technology, \\ 7491 Trondeheim, Norway; yiyu.ding@ntnu.no \\ 2 Erichsen \& Horgen AS, 0484 Oslo, Norway; osk@erichsen-horgen.no \\ 3 Norconsult AS, 8003 Bodø, Norway; stian.fossmo.eliassen@norconsult.com \\ * Correspondence: natasa.nord@ntnu.no \\ + This paper is an extended version of our paper published in Cold Climate HVAC Conference 2018, \\ pp. 505-517. Part of the Springer Proceedings in Energy book series (SPE). DOI: \\ https://doi.org/10.1007/978-3-030-00662-4_42.
}

Citation: Nord, N.; Ding, Y.; Skrautvol, O.; Eliassen, S.F. Energy Pathways for Future Norwegian Residential Building Areas. Energies 2021, 14, 934. https://doi.org/ 10.3390/en14040934

Academic Editor: Jesús Manuel Riquelme-Santos

Received: 22 December 2020

Accepted: 1 February 2021

Published: 10 February 2021

Publisher's Note: MDPI stays neutral with regard to jurisdictional claims in published maps and institutional affiliations.

Copyright: (c) 2021 by the authors. Licensee MDPI, Basel, Switzerland. This article is an open access article distributed under the terms and conditions of the Creative Commons Attribution (CC BY) license (https:// creativecommons.org/licenses/by/ $4.0 /)$.

\begin{abstract}
Owing to stricter building energy requirements, future buildings will be characterized by low base loads and occasional high peaks. However, future building areas will still contain existing and historical buildings with high energy demand. Meanwhile, there is a requirement that future building areas should obtain energy from renewable energy sources, while existing buildings need to be transited to renewables. Therefore, the aim of this study was to develop an approach for modelling energy pathways for future Norwegian residential building areas by analyzing different energy supply systems. Several calculation methods were combined: building simulation, energy supply technology simulation, heat demand aggregation, and data post-processing. The results showed that the energy pathways would be very dependent on $\mathrm{CO}_{2}$-factors for energy sources, and it is hard to predict accurate $\mathrm{CO}_{2}$-factors. An increasing housing stock development would slightly increase the $\mathrm{CO}_{2}$ emissions towards 2050, although the new buildings used much less energy and the existing buildings underwent renovation. A constant housing stock would yield a 22-27\% reduction of $\mathrm{CO}_{2}$ emissions by 2050. This showed that implementing stricter building codes had a lower impact on the total $\mathrm{CO}_{2}$ emissions than $\mathrm{CO}_{2}$-factors and energy technologies. The focus should lie on energy supply systems.
\end{abstract}

Keywords: energy planning; building stock; residential buildings; energy supply; building requirements

\section{Introduction}

Energy planning of the building stock is a highly important topic and highly relevant for energy policy, requirements, and standards development; see Figure 1. Users marked in the mid-part in Figure 1, refer to a town, suburban area, or national building stock, and should be observed when performing building energy planning. The energy demand of users is mainly influenced by two groups; that is, physical and human influenced factors. The first group refers to building envelop, climate, and others that cannot be easily changed. The second group can be changed and is defined by building occupants, which are related to building operation, occupant behavior, and indoor environment conditions [1].

All these issues are highly relevant for our daily life both as individuals and as a society. Stricter requirements in the building regulations require that new buildings reduce energy demand and are characterized by low base load and occasional peaks. However, old buildings will still occupy a large proportion of future building stock, and they provide a complex picture of the future building energy demand. In addition, future building areas shall be provided with renewable energy sources, and the existing buildings need to make 
the transition to renewables. This makes it relevant to look at different energy supply systems and technologies that utilize renewable energy.

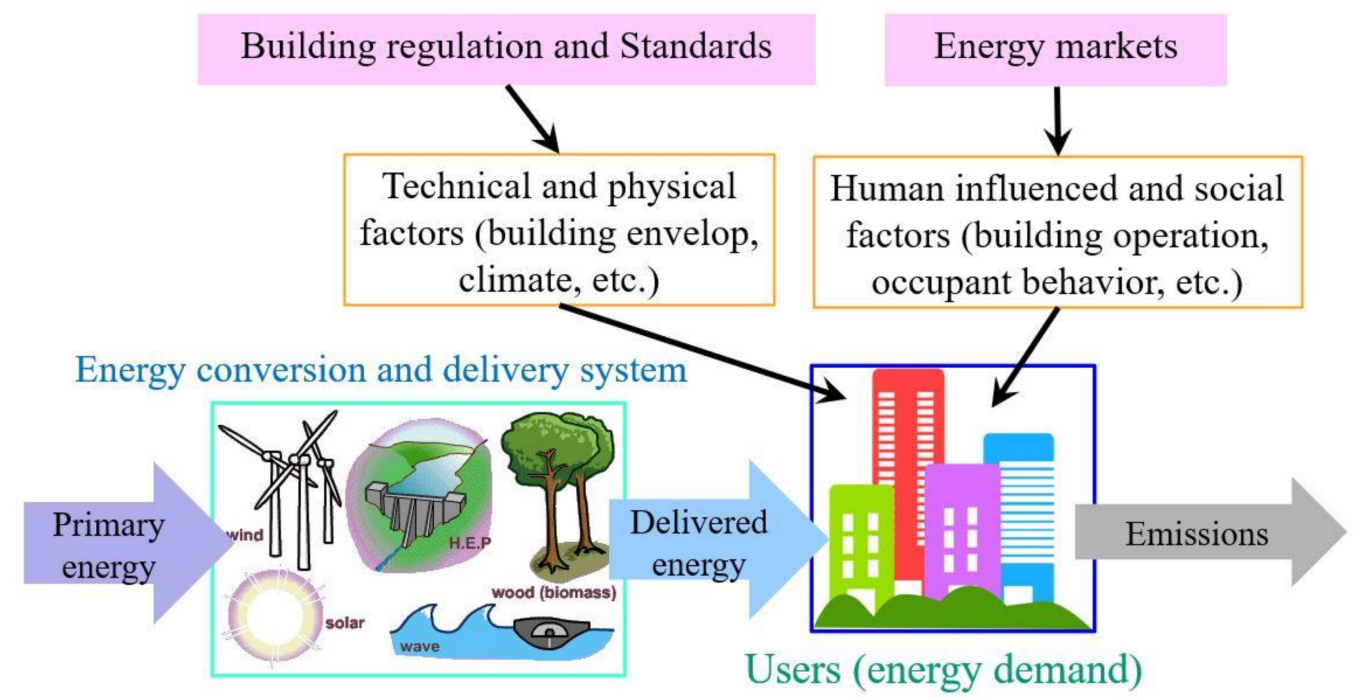

Figure 1. Big picture of urban building energy planning.

Despite its importance, this research topic is still in its infancy, without clear mathematical methods or approaches to cope with all the issues as mentioned above. Although different tools have been developed, they are partially managed to solve the targeted sections and interests [2,3], which can be explained by several reasons such as a fragmented building industry and divergent interests about energy demand and supply.

Among the few transparent tools internationally, they have some limitations on developing building energy requirements, which are supposed to connect building stock identities to energy demand aggregation and corresponding greenhouse gas emissions. For example, the discussion on the last Norwegian building technical requirement, TEK17 (regulations on technical requirements for construction works), showed this problem when the requirement on energy flexibility for building energy supply was removed, because of the government promise to enable cheaper housing. The requirement on energy flexibility that implied possibility for the hydronic heating and connection to the district heating (DH) was diminished: (1) by decreasing the share of energy that should be delivered by the flexible solutions, and (2) by increasing the building area with the energy supply requirement. The energy system's flexibility shall be enhanced to increase the proportion of variable energy sources, which has been addressed in [4]. This meant that there was only a moderate requirement for implementing renewable sources into building stock development. From this Norwegian example, neither energy analysis of building stock nor the directive's influence on the future energy demand were thoroughly considered when making building energy requirements. Current building energy requirements do not guarantee that buildings and building stocks will achieve global environmental requirements, because there are few organizational and institutional structures to support these changes and no useful and transparent energy planning methodology [5]. Hence, there is a lack of tools for energy planning on different levels for different decision makers. To achieve global emission requirements, policy developers, energy planners, energy supply companies, and city planners need a transparent tool and methodology to analyze the possibilities, so that their requirements and ideas would provide a renewable society with very low emissions.

Different methods are suggested to model energy use and emissions of the building stocks. The extrapolation method can estimate values beyond the known range based on the given data. Using this method to consider the building occupant behavior is done by many researchers, for example, to extrapolate office occupancy and operational patterns of windows and to extrapolate the impact from different occupant types; see $[1,6]$. The energy 
solar planning (ESP) tool is a simple tool for municipalities' district planning based on a steady-state monthly energy balance method [3]. Monte Carlo simulation has been used to predict space heating energy use of housing stocks in a bottom-up approach [7], but the model is shown to have uncertainties in prediction. At present, the only software to deal with this topic is the Sustainable Urban Neighbourhood modelling tool (SUNtool) and its recent successor CitySim. Even though these tools deal with occupant behavior, they do not treat energy storage associated with buildings or district energy systems. In [8], the building energy storage has been analyzed with building energy performance simulation, conversion, and local energy potentials to approach a holistic vision of integrated energy systems. Thus, the research field on energy flow modelling of the urban built environment has been growing, but it is still in its infancy $[9,10]$. Only limited progress has been made with respect to modelling of supply from energy conversion systems [3]. The simulation tool for energy planning called EnergyPLAN treats the supply side, while the heating and electricity load of an urban area are inputs [11].

The total greenhouse gas emissions from Norwegian territory were 53.8 million tons of $\mathrm{CO}_{2}$-equivalents in 2014. Among them, there was 1.2 million tons of $\mathrm{CO}_{2}$ equivalents related to heating in other industries and households [12]. Norway is still one of the few countries in which household energy consumption depends on electricity. In 2014, nearly $73 \%$ of Norwegian dwellings had heating based on electricity through electric resistance heaters, heating cables, heat pumps, and central heating, while only around $3 \%$ were based on DH [12]. However, under promotion of the DH network, total consumption of DH in Norway doubled over ten years and reached 5.1 TWh in 2014, where $72 \%$ of $\mathrm{DH}$ was produced from renewable energy sources. One of the motivation factors for looking at different energy supply systems and technologies for the future is to reduce $\mathrm{CO}_{2}$ emissions from Norwegian households. Instead of increasing the utilization of primary energy resources such as hydro, oil, and gas, it may be advantageous in the future to base energy supply on technologies that utilize energy source of ample access to society.

The purpose of the study was to define trends and requirements for building energy supply systems, and to further develop an approach for modelling energy pathways for future residential building areas, by considering different structures of the building areas, implementation of the new requirements for buildings, and energy conversion technologies and combinations. To realize this purpose, different calculation methods were combined: detailed building simulation, energy supply technology simulation, heat demand aggregation, and data post-processing. Building models covering different building codes were developed in IDA ICE. An imaginary building area was synthesized based on the building structure and distribution from current statistics and future projection. The artificial area connected to DH network was treated as representative of the typical Norwegian residential building area. The paper is organized as follows. The methodology is introduced in brief by presenting the main calculation steps. In the result section, energy use of residential buildings at different standards is firstly introduced. Based on the linear projection of the building development, total energy demand until 2050 was presented. The most important performance data of the energy supply plants were introduced. Finally, the $\mathrm{CO}_{2}$ emissions development of the building area over the years is given. Because of the effectiveness of the paper, only the main results are presented from this big study [13]. The sensitivity analysis and criticism on the results are given as comment when relevant.

\section{Materials and Methods}

This study was a combination of the methods from building energy use analysis and energy supply system analysis.

\subsection{Main Information Flow for the Study}

The main information workflow for the study is presented in Figure 2. 


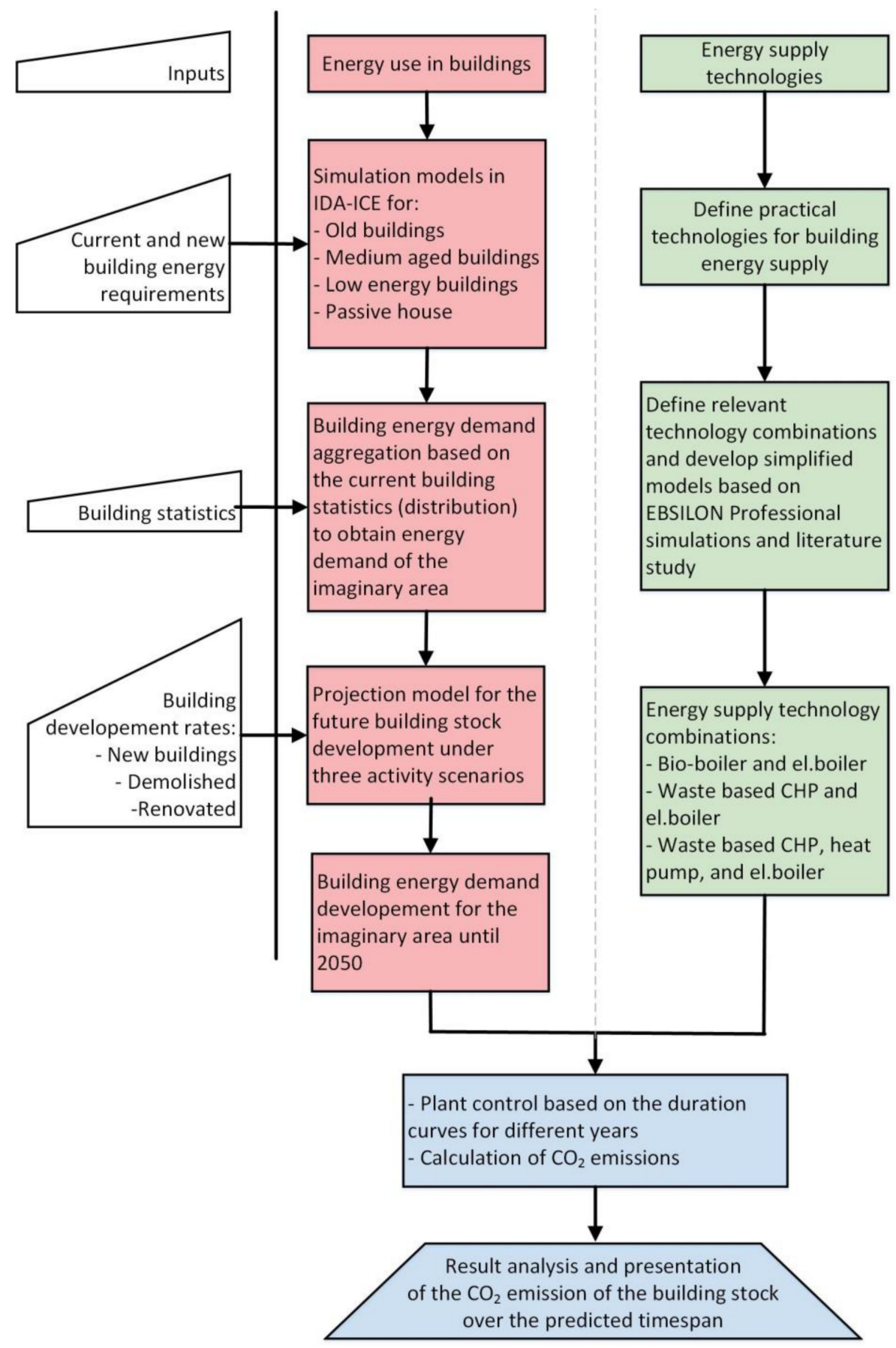

Figure 2. Main information flow for the methodology combining building energy use and energy supply. $\mathrm{CHP}$, combined heat and power.

Firstly, the study focused on the energy use in buildings with the purpose to create different simulation models that presented households according to different standards. Thus, all the building energy classes in Norway were represented. The first part of the method is given on the left side in Figure 2, where the input data are placed in trapezoids and the building models in rectangles. IDA ICE simulation software was used to develop building models based on the historical and current standards. The models regarding different built age cohorts were simulated separately and then aggregated to achieve an imaginary housing area with $72 \mathrm{MW}$ of heat demand and $28 \mathrm{MW}$ of electricity demand. The aggregation is based on housing statistics and statistics from the energy label scheme to obtain an accurate weighting of the housing stock. Furthermore, the housing stock is 
projected with linear growth rates of the energy needs pictures for both today and the future. Additionally, a sensitivity analysis of various user patterns was carried out to see what impact it has on energy needs.

As shown in the right part in Figure 2, the second part of the study dealt with the selection and evaluation of energy supply technologies, by considering the power and energy needs of the housing stock as the input. Energy supply technologies were determined through a literature study of the current renewable energy sources and corresponding $\mathrm{CO}_{2}$ factors $[10,14]$. The combinations of energy supply technologies, as well as power distribution between technologies, were made based on the experience from industrial facilities. The simplified simulation models built in EBSILON Professional software were calibrated with the operation data from similar real plants. From the simplified models, the relationship between the heat and power output and fuel input can be shown by the parametric models. By combining the parametric models and the load of the building stock, a method was developed to control the input of the energy supply technologies based on the building energy needs. Lastly, $\mathrm{CO}_{2}$ emissions were calculated until the year of 2050. The technologies were further evaluated against each other to find the most optimal solution concerning $\mathrm{CO}_{2}$ emissions and other important issues.

\subsection{Single Building Energy Demand}

In this study, a reference building was chosen with a typical two-story single-family house built before 1980, which has a heat area of $122.2 \mathrm{~m}^{2}$ and a ceiling height of $2.5 \mathrm{~m}$. The unit is located at the end of a terraced building to represent the worst-case scenario that three of the outer walls border the open air and one borders the heat area. The heat area was divided into seven thermal zones and the model was built in IDA ICE [15], under the climate data for Oslo, Norway. The IDA ICE model is shown in Figure 3. Energy use in a terraced house is close to the average level of Norwegian residential building types according to statistical data [12]. Thus, to simulate a terraced house is representative to depict the average energy use situation among the dwellings in Norway.

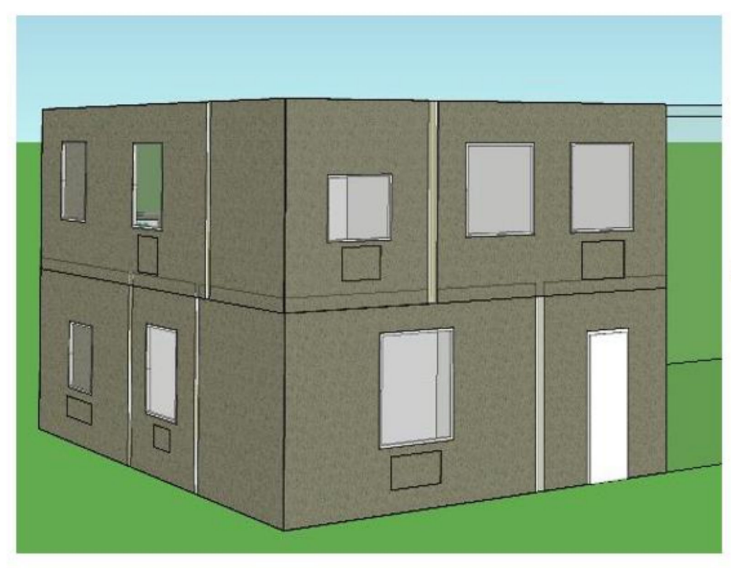

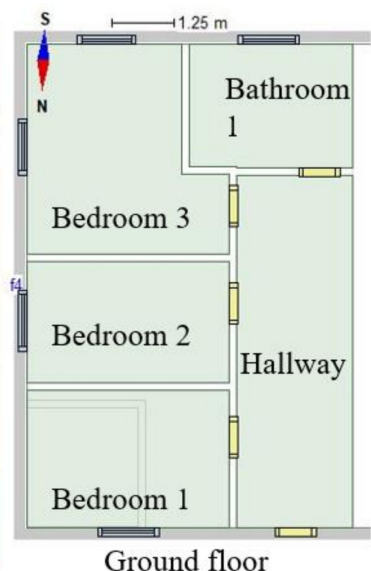

Ground floor

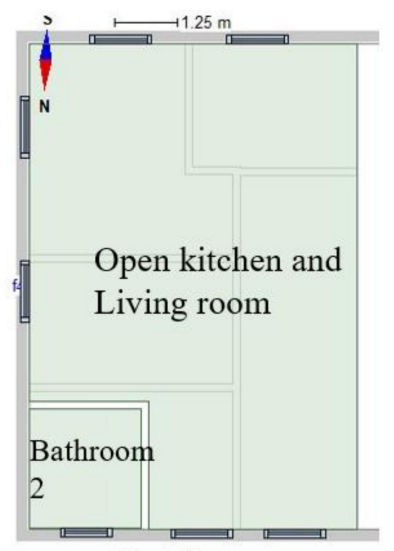

First floor

Figure 3. The reference residential building model in IDA ICE.

To calibrate the energy use of the reference building model, data from the Norwegian Energy Efficiency Agency (Enova) [16], statistical data, and standards were used. Based on NS 3031 [17], the space heating system was designed for a setpoint temperature of $21 / 19{ }^{\circ} \mathrm{C}$ in the occupied/non-occupied hours, respectively, during the coldest period of the year. Radiators were chosen for the heating system. The operation hours for ventilation were set at $24 \mathrm{~h}$ per day, while for heating, lighting, and other electric appliances, they were set at $16 \mathrm{~h}$ per day, all year round. The internal heat gains from solar radiation, lighting, other electric appliances, and people were modelled based on the standard values by concerning the overall heat balance [18]. The net energy for lighting, other electric appliances, 
and domestic hot tap was simulated with $25 \mathrm{kWh} /\left(\mathrm{m}^{2} \cdot\right.$ year $), 26 \mathrm{kWh} /\left(\mathrm{m}^{2} \cdot\right.$ year $)$, and $29.8 \mathrm{kWh} /\left(\mathrm{m}^{2} \cdot\right.$ year $)$, respectively [19].

The reference building model was made as an old building cohort (built before 1980). After its calibration based on the national statistics, different measures were introduced to model the other three built-age cohorts, namely, medium aged buildings, low energy buildings, and passive house buildings. This is to get a realistic approach to the power and energy use of the current and future housing stock by linking historical and current standards. They represent real housing from the period in which they were built. It is thus an effort to create the models with an energy demand at the same level as from Statistics Norway [12]. The improved measures included tighter building physics, modern ventilation, energy-efficient equipment, and so on. The medium-aged buildings represented the existing buildings between 1981 and 2010 and have passed some energy efficiency measures. The model was based on a combination of TEK 87 and TEK 97 owing to its large timespan. Low energy buildings referred to the ones built in 2010 or later by following TEK 10, which specifies the maximum energy limits for different building categories. Passive house also referred to buildings from 2010, but was based on NS 3700. It has a requirement for the highest calculated net energy for heating considering the climate around the building. Table 1 lists all the Norwegian building regulations and standards used in this paper.

Table 1. The Norwegian building regulations and standards used in the study.

\begin{tabular}{cccc}
\hline $\begin{array}{c}\text { Building Code } \\
\text { Acronyms }\end{array}$ & Title & $\begin{array}{c}\text { Year of } \\
\text { Introduction }\end{array}$ & $\begin{array}{c}\text { National Mandatory Regulation/National } \\
\text { Standard Recommendation }\end{array}$ \\
\hline TEK 87 [20] & Regulations on technical & 1987 & National mandatory regulation \\
TEK 97 [20] & requirements for construction works & 2010 & \\
TEK 10 [20] & Criteria for passive houses and & 2017 & National standard recommendation \\
TEK17 [20] & low-energy buildings & 2010 & \\
NS 3700 [21] & Method for greenhouse gas & 2018 & \\
NS 3720 [22] & calculations for buildings & & \\
\hline
\end{tabular}

In this study, detailed hourly values on the heat and electricity demand were used for analysis. Such high quality and high-resolution data were difficult to find in the national statistical data. In general, it was only possible to find the annual specific total building energy use per $\mathrm{m}^{2}$. A summary of all the relevant input data for modelling the single residential building regarding each of the four different built-age cohorts is found in Table 2.

Table 2. Summary of the input data for the building simulation.

\begin{tabular}{|c|c|c|c|c|}
\hline Description & $\begin{array}{l}\text { Old Building } \\
\text { (Before 1980) }\end{array}$ & $\begin{array}{l}\text { Medium Aged Building } \\
\qquad(1981-2010)\end{array}$ & $\begin{array}{l}\text { Low Energy Building } \\
\text { (After 2010) }\end{array}$ & $\begin{array}{l}\text { Passive House } \\
\text { (After 2010) }\end{array}$ \\
\hline The followed standard & $\begin{array}{c}\text { Manual for } \\
\text { enøk normtall }\end{array}$ & TEK $87 / 97$ & TEK 10 & NS 3700 \\
\hline $\mathrm{U}$-value for roof $\left(\mathrm{W} / \mathrm{m}^{2} \cdot \mathrm{K}\right)$ & 0.40 & 0.20 & 0.13 & 0.09 \\
\hline $\begin{array}{l}\text { U-value for floor on ground } \\
\qquad\left(\mathrm{W} / \mathrm{m}^{2} \cdot \mathrm{K}\right)\end{array}$ & 0.40 & 0.299 & 0.15 & 0.08 \\
\hline $\mathrm{U}$-value for external wall $\left(\mathrm{W} / \mathrm{m}^{2} \cdot \mathrm{K}\right)$ & 0.50 & 0.299 & 0.18 & 0.12 \\
\hline U-value for windows $\left(\mathrm{W} / \mathrm{m}^{2} \cdot \mathrm{K}\right)$ & 2.889 & 2.40 & 1.145 & 0.78 \\
\hline $\mathrm{U}$-value for doors $\left(\mathrm{W} / \mathrm{m}^{2} \cdot \mathrm{K}\right)$ & 2.00 & 2.00 & 1.20 & 0.80 \\
\hline U-value averaged $\left(\mathrm{W} / \mathrm{m}^{2} \cdot \mathrm{K}\right)$ & 0.548 & 0.380 & 0.2723 & 0.1922 \\
\hline Normalized cold bridges $\left(\mathrm{W} / \mathrm{m}^{2} \cdot \mathrm{K}\right)$ & - & - & 0.03 & 0.03 \\
\hline $\begin{array}{c}\text { Air change at } 50 \text { Pa pressure } \\
\text { difference }\left(\mathrm{h}^{-1}\right)\end{array}$ & 4.0 & 4.0 & 2.50 & 0.60 \\
\hline
\end{tabular}

\footnotetext{
${ }^{1}$ Houses built before 1980 have no connection to any specific standard. Reference values were thus used for "Old buildings", given by
} Enova in the Manual for Enøk Normtall. 
From Table 2, it can be noted that there is a large decline in the average U-value, from older buildings to passive houses. Further, it can be found that the downward trend of the average U-value has slowed down in recent years. This flattening tendency indicates that the development of dense and compact building bodies has already come a long way, and the improvement potential is not as great as before. For the building model in Figure 3 with the input data given in Table 1, the total specific energy use composition regarding different building standards is given in Figure 4. From Figure 4, it can be noted that energy use was almost halved from the older building to the passive house. The biggest contribution to the reduction came from a significantly lower heating requirement through a better insulated building body. The heating requirement for tap water was almost unchanged, while electricity use was reduced by nearly $40 \%$ owing to the increasing installation of more energy-efficient equipment/lighting and phasing out of the inefficient ones. The results in Figure 4 were also compared with the real measurements and statistics and were found to fit well with the energy measurements. Hence, they were regarded as reliable feeding for further analysis. Cohort study was used in the study by considering different regulations and standards. It is a useful method in the research of building stock development, where each age-cohort group represents a given timespan when each building function is similar in construction and standards. In this study, the dwellings in each built age cohort were thus assumed to have similar energy use under normal operation. It enabled us to build representative models following different standards and then gave a general picture of the building stock. However, the variations such as from construction and operation may have been ignored during the analysis. The previous building research by using cohort analysis and study can be found in [20-25].

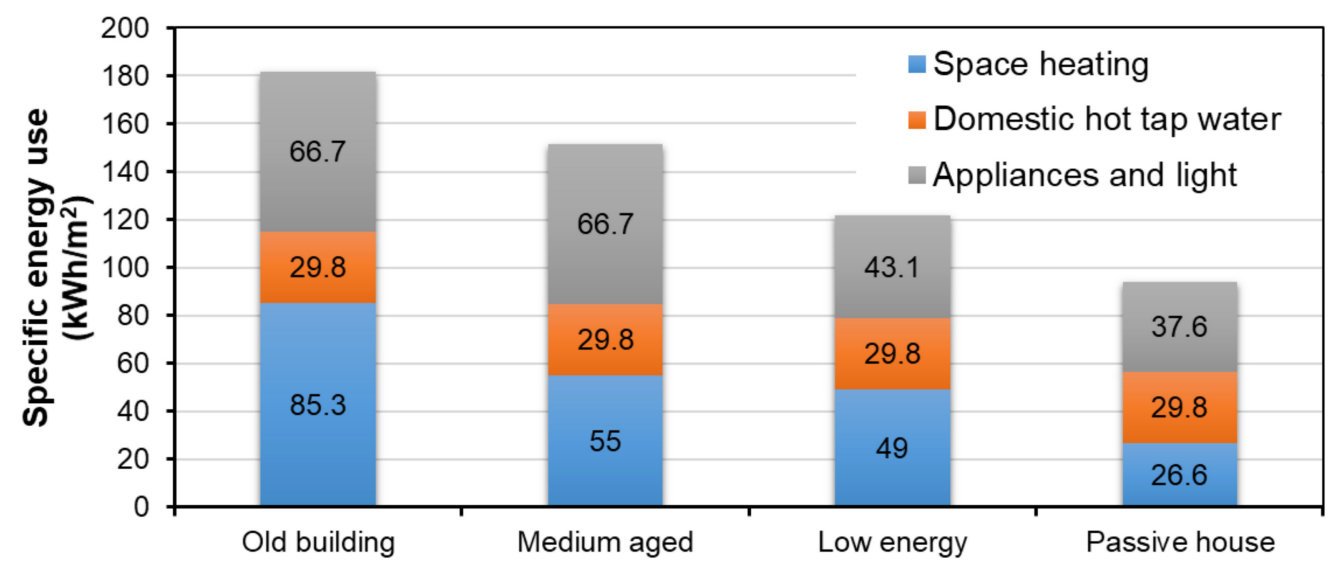

Figure 4. Energy use composition of single building.

For the developed building models, the influence of occupant behavior on the building stock energy demand was also analyzed by considering differences in lighting, electric appliances, and domestic hot tap water use. Sensitivity analysis was performed to see the result variables (energy and power needs) were affected by variation in the input variables. Here, different schedules and demand were implemented for the domestic hot tap water. The greatest energy savings were achieved by having a moderate hot water consumption with a potential annual saving of $8.5 \%$. Different operation schedules and installed power for the appliances and light were treated too. However, it was found out that the optimization of equipment operating hours did not have as great an influence as the hot water use.

\subsection{Building Stock Model}

Energy demand aggregation was based on housing statistics and statistics from the energy labelling system to get an accurate weighting of the housing stock. The percentages in Figure 5 were used for weighting the models to form the housing stock. The pie chart reveals that, currently, most households are older and middle-aged buildings. Passive 
houses make up only $0.1 \%$ of the housing stock, with a marginal impact on the total power and energy needs in 2014, but will have a profound influence by 2050. However, the statistics show the dwelling information including the building types and construction years, without showing the building standard of the dwellings. Therefore, an assumption was made that the building followed the then-standard used in the construction year. Fox example, for a building built in 1998, it was assumed that the dwelling was in accordance with TEK 97. By following the shares of each built-age cohort, it corresponds to nearly 16,373 households based on the energy use from the IDA ICE models, with a total maximum power requirement of $100 \mathrm{MW}$ in total of electricity and heating. Previous research [26] analyzed building areas for both low and heat density regions to point out the challenges and potentials for low-temperature $\mathrm{DH}$ feasibility, which emphasized the connection between energy supply system and building area.

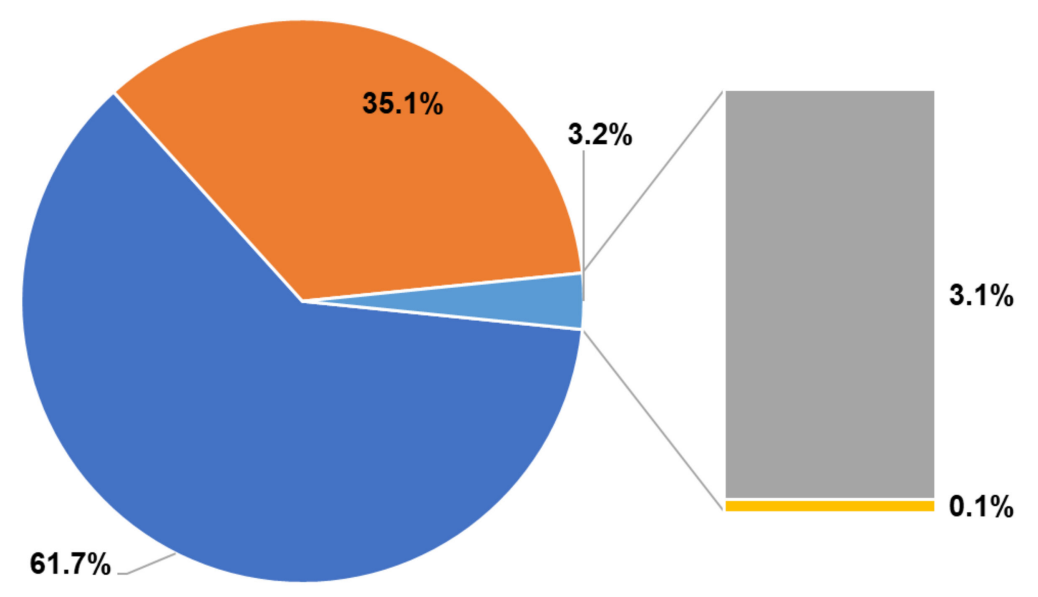

- Old building - Medium aged $\quad$ Low energy $\quad$ Passive house

Figure 5. Weights for the building models and estimated built-age distribution according to building standard in 2014.

Furthermore, to provide an overview of the power and energy needs for today and the future, the future housing stock was projected. Although dynamic modelling can better adjust to changing motivations and political targets in a long-term outlook, as addressed in [25,27], the standard linear trend was chosen in the study. In [28], housing demand was found to almost follow linear growth during certain periods. Moreover, the population increase towards 2050 was projected with a linear tendency based on Statistics Norway [29]. Therefore, the simplification through the linear model was considered competent in this study. As it is outside the scope of this paper to derive the activity rates, the projection rates of new construction, rehabilitation, and demolition were obtained from the report on future building development to the Low Energy Committee [30]. These rates were assumed based on the possible economic development, rather than on achieving certain energy demand reduction of the building stock. A summary of the projection rates for the building stock development is given in Table 3. Using constant growth rates, the short-term fluctuations in the housing stock can be disregarded. As there is great uncertainty about the assumed development, three different scenarios were made for the projection of housing stock in order to capture the uncertainty associated with housing growth, namely, the normal, conservative, and ambitious scenario. According to Table 3 , an analysis on development of the energy demand until 2050 was done under two future housing stock growths. The difference between the new construction rate and the demolition rate yielded a net increase in the housing stock, by concerning population growth and the need for increasing area per person [12]. The second one is a future picture made with a constant housing stock, where the demolition rate was set equal to the new construction rate. The projected housing percentage distribution in 2050 is shown in Table 4 and compared with 2014. 
Table 3. Projection rates for building stock development.

\begin{tabular}{cccc}
\hline Projection Rates (\% per Year) & Normal & Conservative & Ambitious \\
\hline New building rate & 1.33 & $1.06(-20 \%)^{2}$ & $1.66(+20 \%)^{2}$ \\
Rehabilitation rate & 1.50 & $1.06(-20 \%)^{2}$ & $1.80(+20 \%)^{2}$ \\
Demolition rate & 0.6 & $0.48(-20 \%)^{2}$ & $0.72(+20 \%)^{2}$ \\
\hline
\end{tabular}

${ }^{2}$ Numbers in parentheses indicate the percentage reduction/increase based on the normal rates.

Table 4. Comparison of building stock distribution in 2014 and 2050 under the different scenarios.

\begin{tabular}{ccccc}
\hline $\begin{array}{c}\text { Built Age } \\
\text { Cohorts }\end{array}$ & $\begin{array}{c}\text { Distribution } \\
\mathbf{2 0 1 4}\end{array}$ & $\begin{array}{c}\text { Normal } \\
\mathbf{2 0 5 0}\end{array}$ & $\begin{array}{c}\text { Conservative } \\
\mathbf{2 0 5 0}\end{array}$ & Ambitious 2050 \\
\hline & & \multicolumn{2}{c}{ Increased Building Stock } \\
\hline Old building & $61.7 \%$ & $49.7 \%$ & $51.9 \%$ & $47.5 \%$ \\
Medium-aged & $35.1 \%$ & $20.4 \%$ & $22.8 \%$ & $18.3 \%$ \\
Low energy & $3.1 \%$ & $17.8 \%$ & $15.5 \%$ & $20.0 \%$ \\
Passive house & $0.1 \%$ & $42.0 \%$ & $33.2 \%$ & $54.3 \%$ \\
Total & $100.0 \%$ & $129.9 \%$ & $123.3 \%$ & $140.0 \%$ \\
\hline & & Constant Building Stock & \\
\hline Old building & $61.7 \%$ & $38.1 \%$ & $42.0 \%$ & $33.8 \%$ \\
Medium-aged & $35.1 \%$ & $20.4 \%$ & $22.8 \%$ & $18.3 \%$ \\
Low energy & $3.1 \%$ & $17.8 \%$ & $15.5 \%$ & $20.0 \%$ \\
Passive house & $0.1 \%$ & $23.7 \%$ & $19.8 \%$ & $28.0 \%$ \\
Total & $100 \%$ & $100 \%$ & $100 \%$ & $100 \%$ \\
\hline
\end{tabular}

During the modelling, four assumptions were considered:

- Only older buildings were demolished.

- Rehabilitation of middle-aged buildings achieved low energy building standard.

- New buildings were built according to the passive house standard.

- Passive houses are the "best" building standard.

\subsection{Energy Supply System and $\mathrm{CO}_{2}$ Emissions}

To combine hourly heat and electricity demand with the energy supply technologies, parametric models were used, as explained in Section 2.1. The parametric model included performance data under the part load. Depending on the energy supply scenario (see Table 5), the plants were controlled in the combination of base and peak load plant. The plants with high investment cost and low energy cost were treated as the base load plants, while the ones with the low investment and high energy cost were considered as peak load plants. The sizes of the plants in Table 5 were obtained based on the cost-optimal approach explained in $[10,31]$. Some of the most important reasons to have multiple technologies are as follows: reduction in total investment costs, improvement in supply security and part load efficiency, and flexible ability of choosing the most affordable energy sources. In this study, only renewable energy sources were chosen. Combustion of biofuels with electric boiler is a popular solution in Norway, owing to local rich bio-resources and fast response from electric boiler. Combined heat and power (CHP) plant from waste incineration and electric boiler offers a more flexible solution through optimization of energy production according to price and demand, helping to stabilize the electricity grid if needed. The combination of waste-based CHP, electric boiler, and heat pump can further enhance the flexibility of the heating system with the opportunity of choosing the cheapest energy sources and utilizing low-grade heat. 
Table 5. Scenarios of energy supply combination. CHP, combined heat and power.

\begin{tabular}{ccc}
\hline Scenario & Energy Production (Heat Demand) & Required Rate (MW) \\
\hline \multirow{2}{*}{ F1 } & $90 \%$ Bio-boiler & 33.1 \\
& $10 \%$ Electrical boiler & 38.7 \\
F2 & $90 \%$ Waste-based CHP & 33.1 \\
& $10 \%$ Electrical boiler & 38.7 \\
F3 & $80 \%$ Waste-based CHP & 25.6 \\
& 20\% Electrical boiler & 46.2 \\
F4 & $67.7 \%$ Waste-based CHP & 19.0 \\
& $22.3 \%$ Heat pump & 14.3 \\
& $10 \%$ Electrical boiler & 38.5 \\
\hline
\end{tabular}

The control of the plants was organized as follows: when the heat load at an observed moment was lower than the full base load plant, then that plant was operating under the part load. When the observed load was higher than the full base load plant, the second plant was started. Depending on the rest load, the second or the peak load plant was operating on part load until all the demand was met. The hourly calculation for each year considered the changes in the duration curves, thereby energy demand concerning building stock change was calculated.

The required fuel of each year was calculated on energy demand and the efficiency of energy conversion technologies. To make it easier, the plant efficiencies for fuel input were assumed constant under normal operation, and their values are found in Table 6. After the fuel and energy inputs were calculated over different years, the $\mathrm{CO}_{2}$ emissions were estimated using the factors given in Table 7 recommended in [32]. There have been lots of discussion regarding the values on the $\mathrm{CO}_{2}$ emission factors. Depending on the institution, the values of electricity vary from $3 \mathrm{~g} \mathrm{CO}_{2} \mathrm{e} / \mathrm{kWh}$ [33], if only the Norwegian hydro power is considered, up to $493 \mathrm{~g} \mathrm{CO}_{2} \mathrm{e} / \mathrm{kWh}$ [33] if the guarantee of origin for the renewable electricity is treated in the EU's guarantee of origin. For the $\mathrm{CO}_{2}$ emissions allocation in the CHP plant, the work was done by following the "Energy method", with the consideration of heat and electricity production amount. Previous research using this method and discussion with other methods can be found in [14,34,35]. Additionally, the impact of distribution losses in the DH network was not included in the article. As the heat losses and infrastructure would be the same for all the studied scenarios, the $\mathrm{CO}_{2}$ load was assumed to be unchanged between the systems.

Table 6. Energy efficiency values of the considered energy conversion technologies.

\begin{tabular}{cc}
\hline Energy Conversion Technologies & Efficiency (\%) \\
\hline Waste-based CHP & 90 \\
Electrical boiler & 95 \\
Bio-boiler & 85 \\
Heat pump & $3^{3}$ \\
\hline
\end{tabular}

${ }^{3}$ refers to COP of the heat pump.

Table 7. Recommended $\mathrm{CO}_{2}$ emission factors [32].

\begin{tabular}{cc}
\hline Energy Sources & Total $\left(\mathbf{g C O}_{\mathbf{2}} \mathbf{e} / \mathbf{k W h}\right)$ \\
\hline Electricity (Nordic production mix) & 110 \\
Municipal waste (with sustainable criteria) & 11 \\
Municipal waste (without sustainable criteria) & 175 \\
Wood chips & 18 \\
Pellets and wood powder & 19 \\
Heat pump driven by electric compressor & 110 \\
\hline
\end{tabular}

In Table 7, for the municipal waste with sustainable criteria, this meant the waste without fossil waste and this value was used in the study by considering the $\mathrm{CO}_{2}$ involved 
in transportation and other process. Because of the new Norwegian standard NS 3720 [22], this value can also be regarded as zero when waste incineration is used for energy production such as electricity and/or heat. As for the $\mathrm{CO}_{2}$ emissions from the heat pumps, it refers to the $\mathrm{CO}_{2}$ emissions from the electricity used by the heat pump in the analysis, which only used electric-driven heat pumps. All the values may change over the years, but this was not treated in this study. For analysis purposes, different values for the $\mathrm{CO}_{2}$ emissions were considered and commented.

\section{Results}

This section gives a brief summary of the most relevant results regarding the main idea of the procedures to decrease the $\mathrm{CO}_{2}$ emissions of the building stock. These results can give suggestions for future building stock development.

\subsection{Energy Demand of the Building Stock and Future Development}

Based on the method introduced in the flowchart in Figure 2, the total energy and power demand of the observed building area is obtained by combining the data on development of building energy use in Figure 4 and the building stock development in Table 3. As shown in Figures 6 and 7, both the cases of increased and constant building stock were analyzed. After the building structure and distribution of the area is defined, the building stock at a national scale can be extrapolated from that. Therefore, the results of heat and electricity demand stacked in Figures 6 and 7 can be regarded as the representation of the national trend in building energy demand under normal development rates.

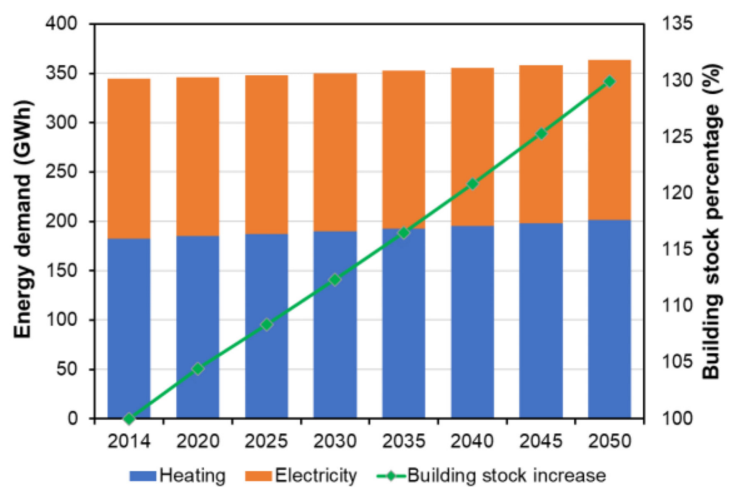

(a)

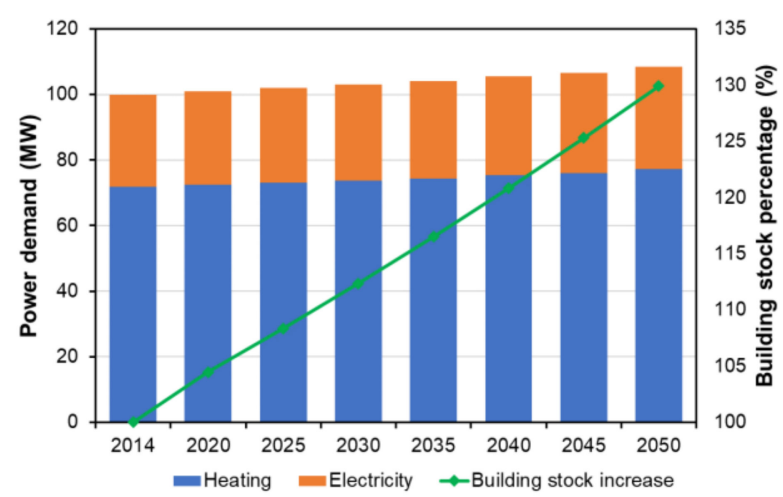

(b)

Figure 6. (a) Total energy demand of the increased building stock with normal development rate; (b) total power capacity demand of the increased building stock with normal development rate.

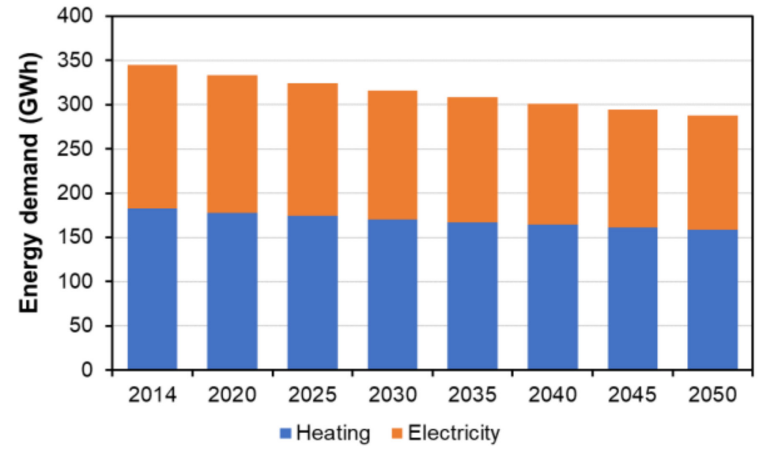

(a)

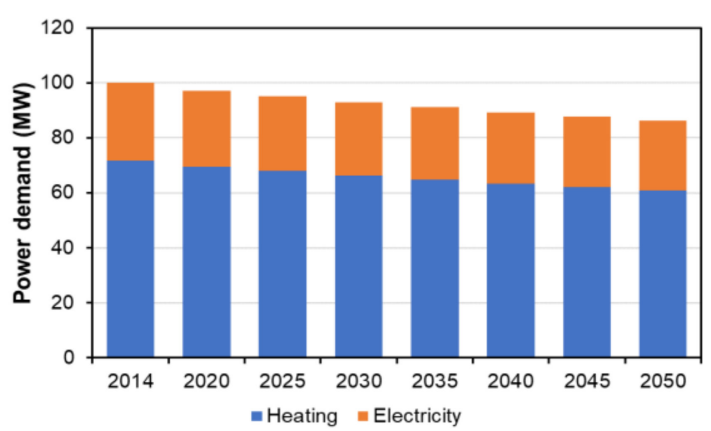

(b)

Figure 7. (a) Total energy demand of the constant building stock with normal development rate; (b) total power capacity demand of the constant building stock with normal development rate. 
The results in Figure 6 demonstrate that the total energy and power demand will increase if the increased building stock would be introduced, regardless of a significant decrease in single building energy demand, as shown in Figure 4, by performing renovation and promoting penetration of passive houses. From Figure 6, it can be found that energy demand increases by $5.4 \%$ and an $8.4 \%$ higher capacity would be needed in the case of a $29.9 \%$ increase in building stock by 2050 see Table 4 . Moreover, the share of heating demand was slightly increasing from $53 \%$ in the beginning to $55.5 \%$ by 2050 . Whereas, in the case of the constant building stock with equal rates for both new building construction and demolishment, the total energy demand and capacity needs would decrease by $16.6 \%$ and $13.8 \%$, respectively, as shown in Figure 7. Again, the proportion of heating demand had the similar small growth as the increased building stock above. Additionally, from the sensitivity analysis considering occupant behavior, for example, the hot water use and equipment use as mentioned in Section 2.2, it was found that the results in Figures 6 and 7 and may vary by up to $10 \%$.

\section{2. $\mathrm{CO}_{2}$ Emissions of the Building Stock}

\subsubsection{Based on the Current $\mathrm{CO}_{2}$ Factors for the Energy Sources}

Based on the heat demand and energy supply systems defined in Table 5, the $\mathrm{CO}_{2}$ emissions for the increased building stock were calculated, as obtained in Figure 8. The ambitious scenario is shown in solid lines, the conservative building stock activity is in dotted lines, and the normal activity stands in between (not showed in the plot for easy reading). They were compared with columns for both ambitious and conservative building stock increase. The shortcuts were used to mark each energy supply scenario, which can be found in Table 5. The year 2014 was considered as the reference year, as the building stock model was developed based on the building stock structure and distribution in 2014.

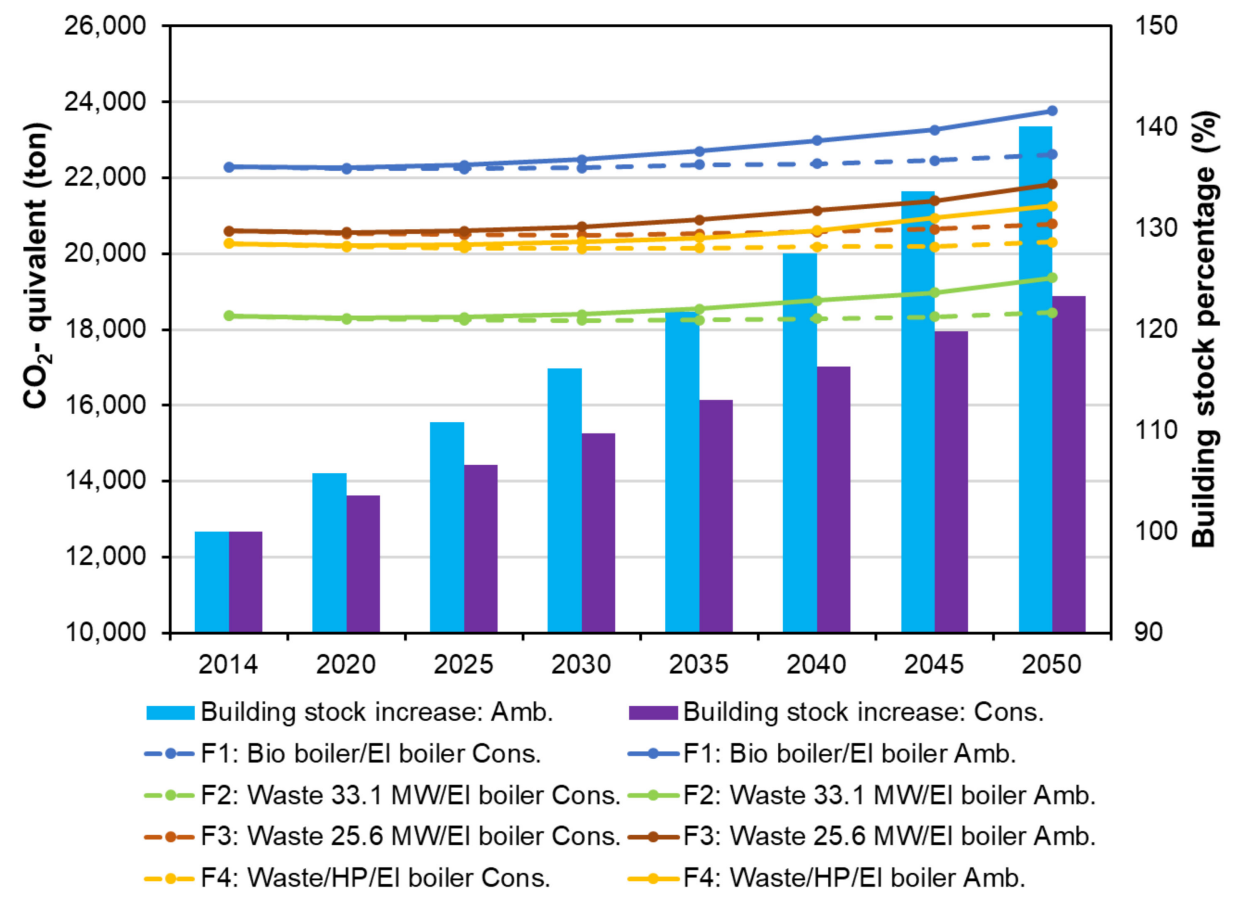

Figure 8. $\mathrm{CO}_{2}$ emissions of the increased building stock considering different development rates.

Depending on the technology choice, the extent of $\mathrm{CO}_{2}$ emission growth may be varied. In Figure 8, energy supply system F2-combination of waste-based CHP (33.1 MW) and electric boiler had the lowest $\mathrm{CO}_{2}$ emissions over the whole analysis period. The second-best solution came with energy supply system F4-combination of waste-based CHP, heat pump, and electric boiler, which had 10.3\% higher emissions than F2. The emissions from the combination of waste-based CHP (25.6 MW) and electric boiler were 
$12.2 \%$ higher than those of F2. The worst energy supply system is F1-combination of biofuel boiler and electric boiler, by having $21.3 \%$ higher emissions than F2. In general, by 2050, $\mathrm{CO}_{2}$ emissions would increase by only between 0.2 and $6.7 \%$ under $23-40 \%$ building stock growth compared with 2014. Meanwhile, the allocation of $\mathrm{CO}_{2}$ emissions for the different energy supply systems under the normal scenario is given in Figure 9, where the blue blocks are for $\mathrm{CO}_{2}$ from heat production, the marginal orange blocks are for $\mathrm{CO}_{2}$ from electricity in the CHP plant, and the grey blocks for the $\mathrm{CO}_{2}$ from the power grid. In this study, the allocation factor for electricity was given as between 0.18 and 0.20 , and that for heat as between 0.80 and 0.82 .

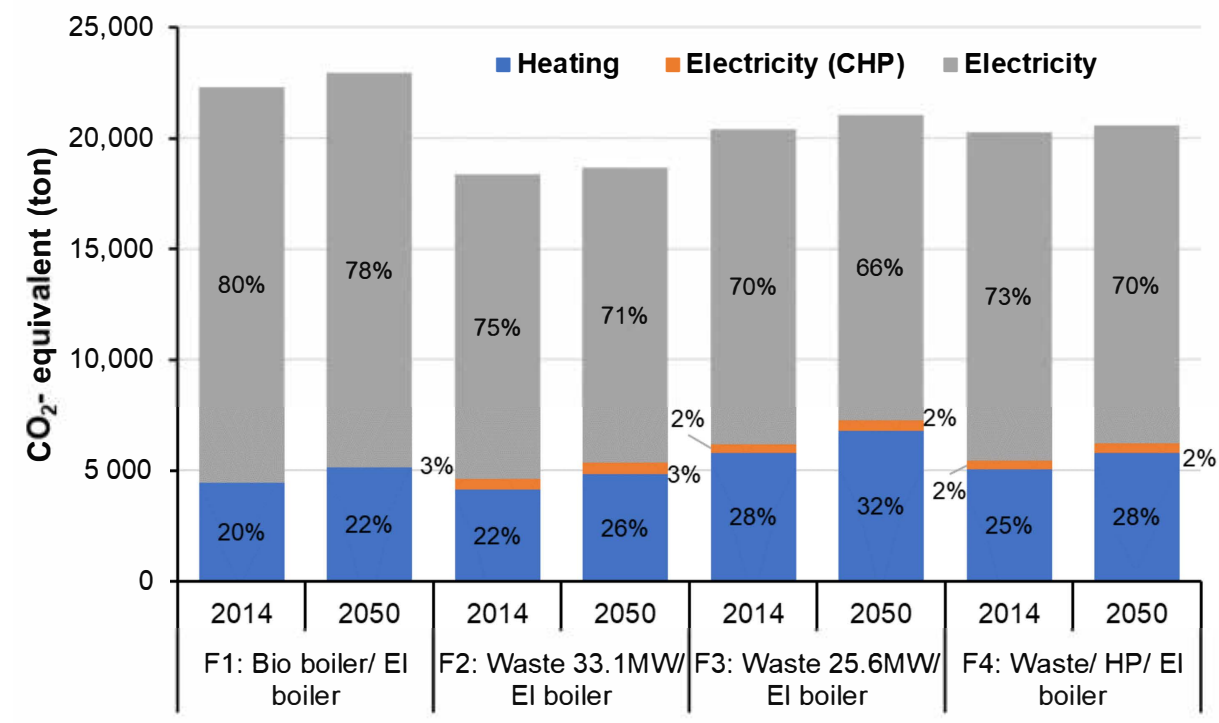

Figure 9. Allocation of the $\mathrm{CO}_{2}$ emissions for the different energy supply technologies for the increased building stock.

By following the same method as above, $\mathrm{CO}_{2}$ emissions and its allocation under normal scenario concerning the constant building stock are shown in Figures 10 and 11, respectively. Similar to the increased building stock activity, energy supply combination F2 still gave the lowest $\mathrm{CO}_{2}$ emissions over the time span and yielded 21.6-9.5\% $\mathrm{CO}_{2}$ reduction of the level in the reference year. Energy supply solution F1 had the worst performance with $25.2 \%$ higher $\mathrm{CO}_{2}$ emissions than $\mathrm{F} 2$, while solution $\mathrm{F} 3$ and $\mathrm{F} 4$ were in the middle.

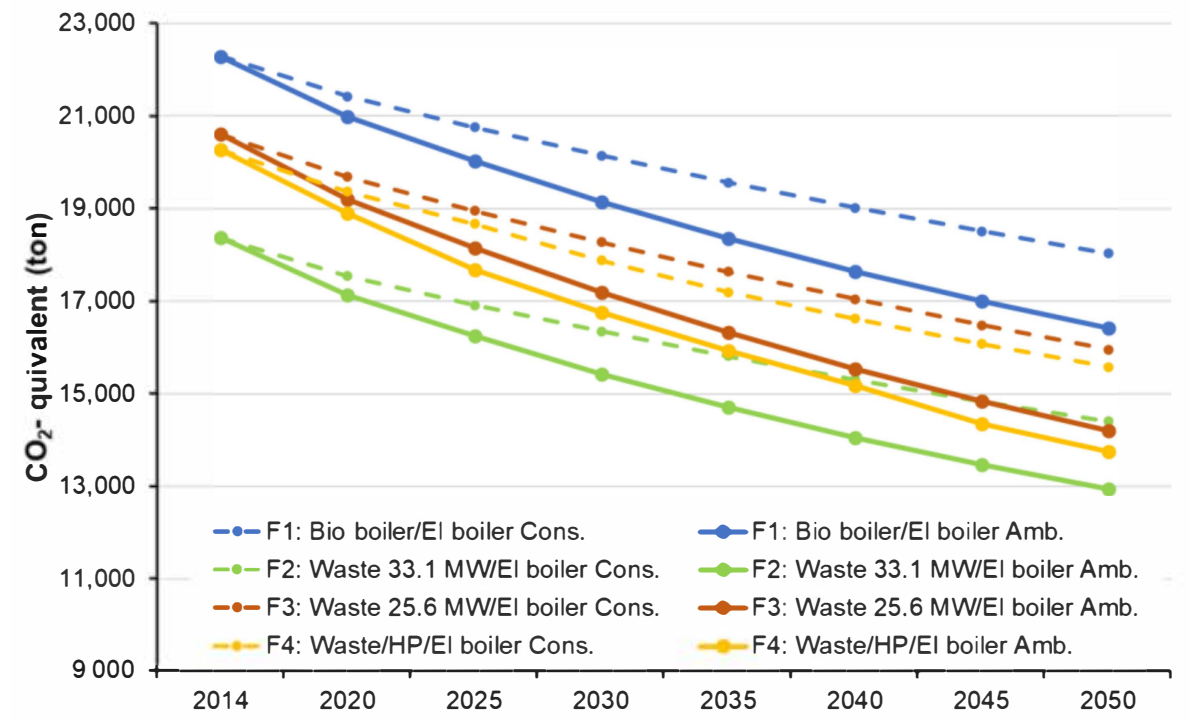

Figure 10. $\mathrm{CO}_{2}$ emissions of the constant building stock considering different development rates. 


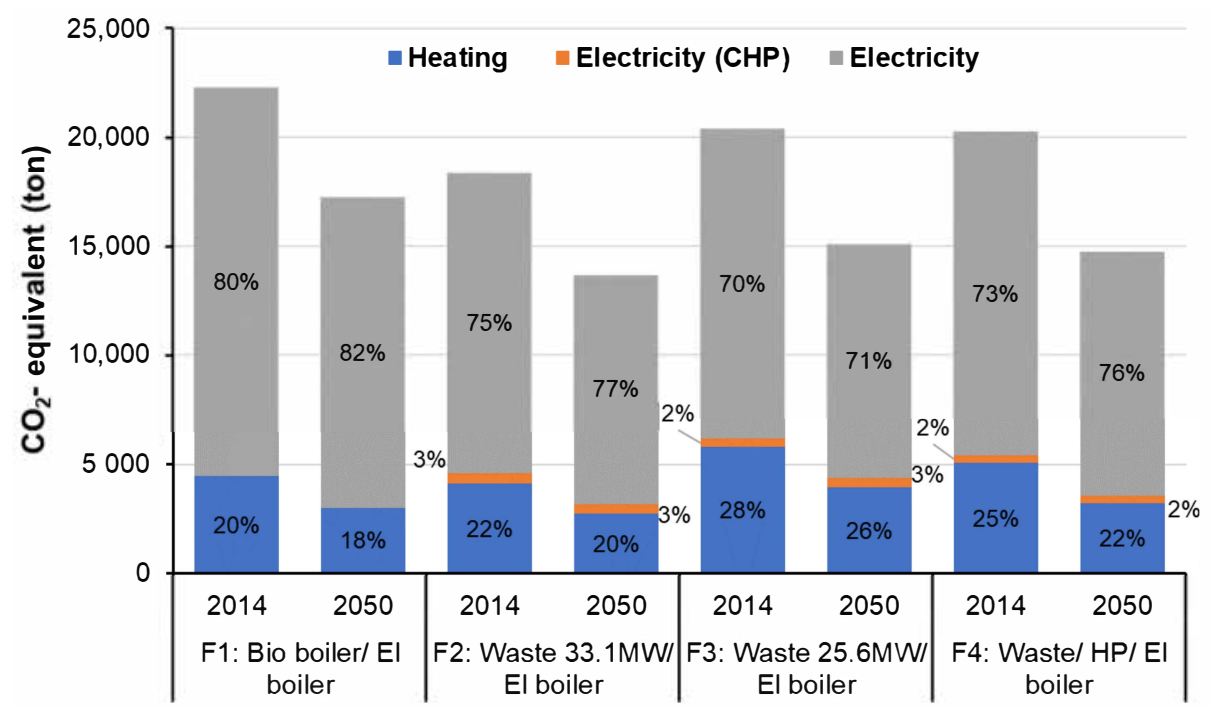

Figure 11. Allocation of the $\mathrm{CO}_{2}$ emissions for the different energy supply technologies for the constant building stock.

Both Figures 9 and 11 showed that the largest share of $\mathrm{CO}_{2}$ emissions was related to electricity production mix from power grid in both 2014 and 2050. In addition, it might be noted that the combinations including the waste-based $\mathrm{CHP}$ plant provided lower $\mathrm{CO}_{2}$ emissions in general; see Figures 8 and 10. This is mainly because the electricity made from the CHP plant is usually considered as the by-product of heat and can reduce other resources of high carbon contents to produce electricity.

Further, to show what may give the biggest decrease of the $\mathrm{CO}_{2}$ emission of the residential building stock in Norway, a comparison of the $\mathrm{CO}_{2}$ emissions for the constant building stock and the increased building stock was made in Figure 12, based on a normal scenario for housing development. The $\mathrm{CO}_{2}$ emissions with an increased and a constant building stock are shown in the solid lines and dotted lines, respectively. The $\mathrm{CO}_{2}$ emissions gradually decrease towards 2050 under constant building stock. This decline shows how much an upgraded housing stock with a reduced energy requirement can save $\mathrm{CO}_{2}$ emissions. The results show that the constant building stock would yield a higher decrease in the $\mathrm{CO}_{2}$ emission by $25-28 \%$ than the increased building stock. This means that the implemented energy-efficiency renovation rates and penetration of the new houses would not suffice to give a significant decrease in the $\mathrm{CO}_{2}$ emission of the building stock.

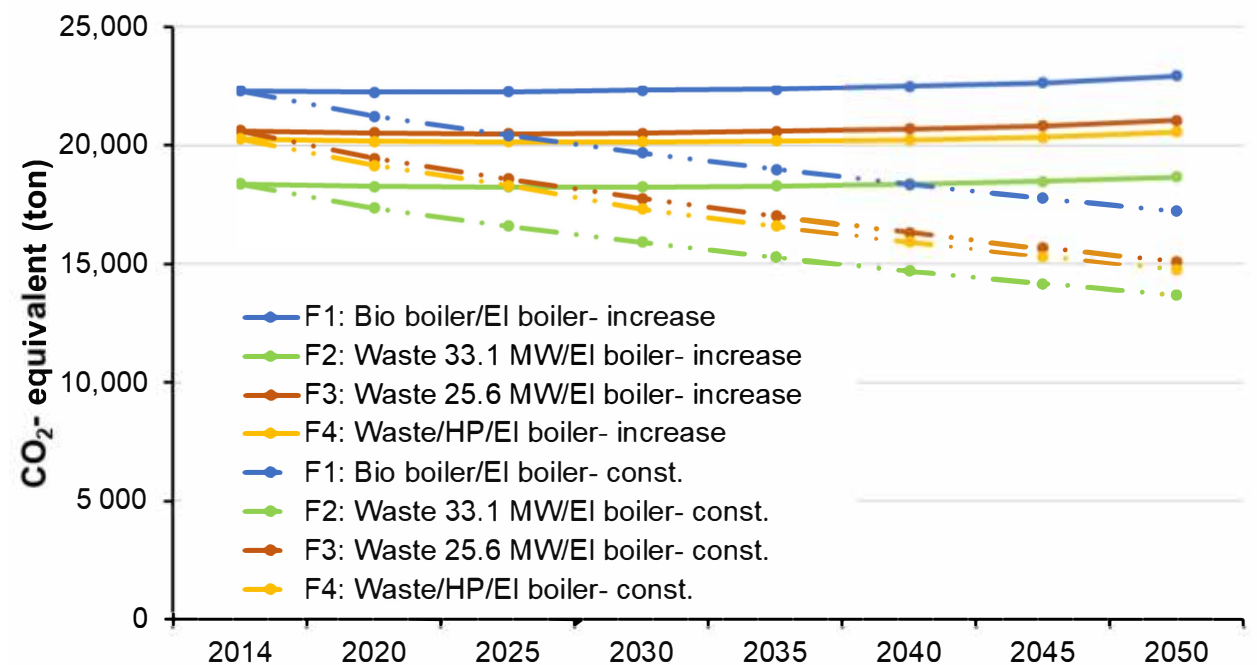

Figure 12. Comparison of the $\mathrm{CO}_{2}$ emissions for the increasing and constant building stock. 


\subsubsection{Based on the Annual Reduction of $\mathrm{CO}_{2}$ Factor for Electricity Production Mix}

The results of $\mathrm{CO}_{2}$ emissions in Section 3.2.1 were estimated based on the constant factors in Table 5. As presented above, the $\mathrm{CO}_{2}$ factor for electricity is the most prominent variable in the $\mathrm{CO}_{2}$ calculations. In the study, the factor from the Nordic electricity production mix, $110 \mathrm{~g} \mathrm{CO}_{2} \mathrm{e} / \mathrm{kWh}$, was used. It considers comprehensively the green Norwegian hydropower and fossil fuels in other Nordic countries, which have ambitions and plans to increase the share of renewable energy in the electricity production. It may have a positive influence of the carbon intensity in the grid. On the other hand, there are grid expansion plans to connect more European countries with currently higher involvement of fossil fuels, which may bring a negative impact [36]. Therefore, it is rather difficult to predict the future development of $\mathrm{CO}_{2}$ factors.

In this study, an attempt was made to reduce the $\mathrm{CO}_{2}$ factor for the Nordic production mix by $1 \%$ each year until 2050 (see Figure 13), where the dashed and dotted lines illustrate the $\mathrm{CO}_{2}$ emissions with a $1 \%$ decrease per year. This is made to reveal how decisive the factors are, and how the development of $\mathrm{CO}_{2}$ emissions is affected. By 2050, $\mathrm{CO}_{2}$ emissions may be reduced by between 28 and 30\% under the normal increased building stock activity, instead of an increase of between 1.4-2.9\% using the constant factors over the time span. Lastly, by comparing with a constant building stock yielding $25-28 \%$ of $\mathrm{CO}_{2}$ reduction in Figure 10, it thus implies the $\mathrm{CO}_{2}$ factors and background data have a greater impact on $\mathrm{CO}_{2}$ emissions than the energy demand reduction and development of the building stock.

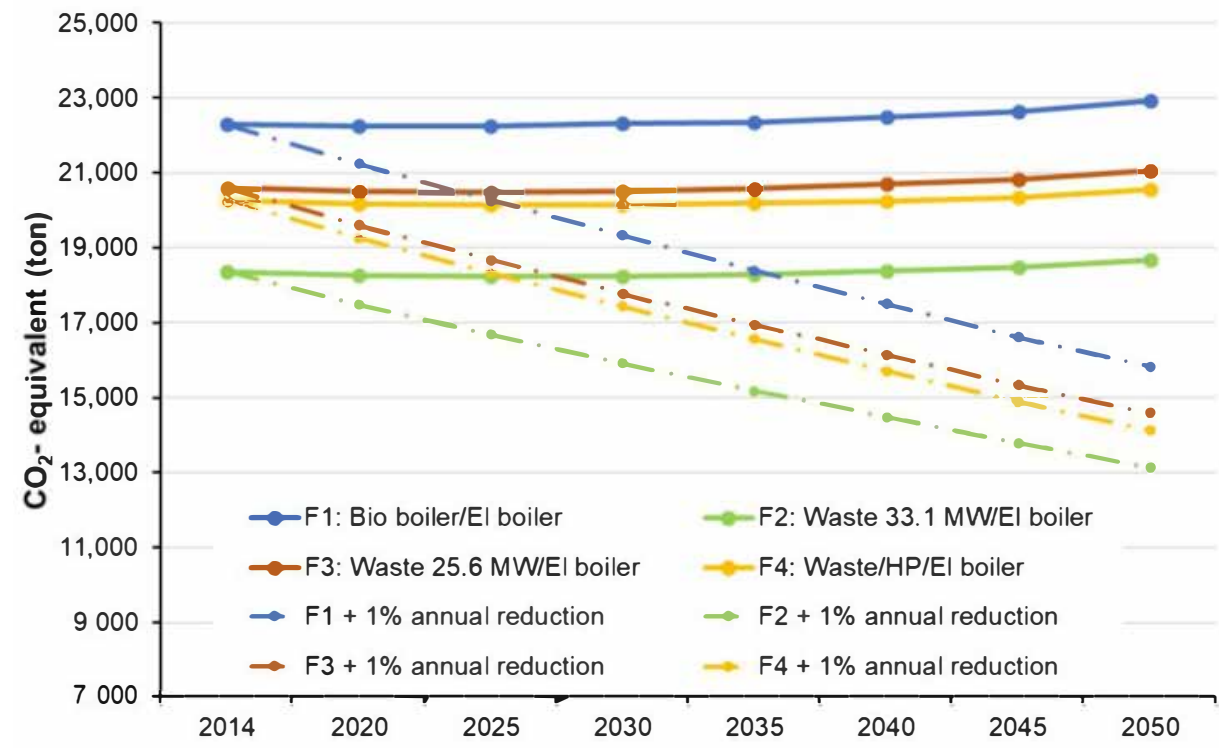

Figure 13. $\mathrm{CO}_{2}$ emissions with a $1 \%$ annual reduction in $\mathrm{CO}_{2}$ factor for electricity production mix.

\section{Discussion}

In this section, the issues regarding $\mathrm{CO}_{2}$ factors, waste incineration, and future energy technologies development are discussed.

First, in the study, the $\mathrm{CO}_{2}$ factors recommended by the industry association Norsk Energi were chosen as constant values for $\mathrm{CO}_{2}$ estimation from today to 2050. For electricity, the recommended factor is $110 \mathrm{~g} \mathrm{CO}_{2} \mathrm{e} / \mathrm{kWh}$ considering the open market in the Nordic region for power trading.

Norway is part of the EU's guarantee of origin scheme and is the country that exports the most guarantees. This is because of the great interest from the countries with a low proportion of renewable energy production. As a result, most of the power sold in Norway receives a product declaration with high $\mathrm{CO}_{2}$ emissions, based on a European residual mix consisting of coal and nuclear power. It can be discussed how large the impact of guarantee selling is for Norway's $\mathrm{CO}_{2}$ emissions, and how much development of renewable energy production in Europe has been stimulated by such guarantees. The Norwegian industry 
associations that represent power-intensive industry are critical of the guarantee of origin and believe that it leads to undermining of the renewability of Norwegian power, as the total power sales in Norway show much higher $\mathrm{CO}_{2}$ emissions on paper.

It can also be discussed whether it is a good resource utilization to use high-value energy such as electricity for heat use, some of which could rather have been exported to areas with low renewable energy proportion. The use of fossil energy sources in these areas could then have been reduced. For example, to expand the utilization of local heat source such as waste incineration and industrial excess heat can lower the domestic electricity reliance in Norway $[37,38]$.

It is thus difficult to predict the $\mathrm{CO}_{2}$ factor for electricity, as it highly depends on the production and trading activities from all the players on grid.

Second, waste incineration is the largest energy resource for the Norwegian $\mathrm{DH}$ network, by contributing more than $50 \%$ of the total $\mathrm{DH}$ production. This is largely due to the landfill ban since 2009, leading to an increase in the development of new energy facilities. In addition to the profits from selling heat, the plants also get paid according to the amount of treating waste. This might cause the plant managers overlook the unit operation efficiency and invest in over-capacity units. This contrasts with biofuel plants, which usually ensure the operation is maintained at high efficiency. Another disadvantage of waste incineration plants is the limitation of partial load conditions. In most cases, it is not possible to down-regulate the effect by more than $50 \%$ of nominal performance, which means that it may have over production that needs to be dumped. Although poor energy utilization may happen, it is conceivable that it is better to incinerate the waste than to dispose from an environmental point of view, but $\mathrm{CO}_{2}$ attributed to over production may be considered. Additionally, for the allocation of $\mathrm{CO}_{2}$ emissions from simultaneous production of heat and electricity in a CHP process, the "Energy method" was adopted. Although it is simple and widely used, it only considers the amount of produced heat and electricity other than the energy quality. It may be argued that the proportion of $\mathrm{CO}_{2}$ emissions allocated to electricity production was somehow underestimated. Other advanced allocation methods shall be used and compared, which are referred to in $[34,39]$.

Third, in the study, four energy conversion technologies were selected based on their maturity, social acceptance, and feasibilities of using renewable sources, namely, bio boiler, waste CHP, heat pump, and electric boiler. They are further developed into four energy supply systems with different combinations. Other alternative technologies were not included in this study, such as solar energy and carbon capture and storage (CCS), even though they have the potential to further reduce the total $\mathrm{CO}_{2}$ emissions. It would thus have been relevant to see the impact from the involvement of solar energy and CCS on the future energy supply systems in relation to other ones, as evaluated in [40], to achieving the 2050 decarbonization target, where solar energy was found to be more favorable than CCS for the British case, and [41] found that a 100\% renewables-based system including solar energy could be cheaper than CCS-assisted nuclear and fossil-based system for Eurasian grid. Moreover, there are no accounts that have been taken on the future technology costs' reduction due to improved maturity and the embedded $\mathrm{CO}_{2}$ emissions in the development of infrastructure and losses in the DH distribution network, which shall be looked at more closely. Therefore, techno-economic analysis on payback period and the whole life cycle costs may be interesting for future study, as performed in [42].

\section{Conclusions}

This study has addressed energy paths for the future development of residential building areas, with the aim to analyze and define the trends and requirements in energy supply technologies and systems. To address the task, building energy performance models were developed in IDA ICE by following different building standards, which presented different building categories in a Norwegian housing stock. It was found that the total energy use was nearly halved from the older building to the passive house, with the biggest contribution from lower heating requirement owing to the enhanced building physics. 
Future building stock distribution and development was projected under three scenarios based on possible economic development. Next, four energy supply technologies regarding the base and peak load solutions were developed in EBSILON Professional, where the goal was to look at which solution(s) gave the lowest $\mathrm{CO}_{2}$ emissions by 2050 . Using the recommended $\mathrm{CO}_{2}$ emission factors, the waste-based $\mathrm{CHP}$ in combination with the electric boiler gave the lowest $\mathrm{CO}_{2}$ emissions, with a margin of $10.3 \%$ in 2014. Furthermore, the energy supply system with the waste-based CHP in combination with the heat pump and the electric boiler gave the second-best results. The poorest results were obtained for the energy supply system with bio boiler and electric boiler, which had $\mathrm{CO}_{2}$ emissions $21.3 \%$ higher than the best one.

In the scenario of increasing housing building stock, it is apparent from the results that $\mathrm{CO}_{2}$ emissions increase slightly towards 2050 when seeing all the energy supply systems, despite the fact that the passive houses that were being built would use only half the energy of the existing buildings that were being demolished. This indicates that much stronger activities on the building renovation are highly necessary. The renovation rates used in this study seem to be not good enough. In a scenario with a constant housing stock, $\mathrm{CO}_{2}$ emissions were estimated to be reduced by between 22 and $27 \%$ depending on which energy supply system was analyzed.

Meanwhile, the results would change when using the $\mathrm{CO}_{2}$ factors from other sources. An attempt was made to reduce the $\mathrm{CO}_{2}$ factor for the Nordic electricity production mix by $1 \%$ each year until 2050. The $\mathrm{CO}_{2}$ emissions may be reduced by between 28 and $30 \%$ under the normal increased building stock activity, by giving more promising results than $\mathrm{CO}_{2}$ reduction under the case of constant building stock. This shows that the choice of $\mathrm{CO}_{2}$ factor is very important for the results, especially the $\mathrm{CO}_{2}$ factor for electricity. However, different companies and organizations often operate with different $\mathrm{CO}_{2}$ factors to substantiate their own interests, so it can be difficult to assess which $\mathrm{CO}_{2}$ factors are provided on the most objective basis. The findings can be applied to other regions such as the similar cold climatic areas, which require alike specific building energy demand, and areas having a similar $\mathrm{CO}_{2}$ background of energy sources. The methodology regarding modelling and modification of single building energy demand, aggregation of building stock, and energy system combinations can be adjusted to regions according to their own characteristics.

In summary, the results show that implementation of stricter construction regulations has a positive impact on $\mathrm{CO}_{2}$ emissions. However, it has less of an impact on emissions than the choice of energy sources and conversion technologies, because the energy sources gave a bigger reduction of the $\mathrm{CO}_{2}$ emissions. The results and conclusions in this study might have some limitations owing to all the assumptions made. However, the findings might give some recommendations on building energy planning and choosing energy supply sources.

Author Contributions: Conceptualization, N.N., O.S., and S.F.E.; methodology, N.N., O.S., and S.F.E.; software, O.S. and S.F.E.; validation, O.S. and S.F.E.; formal analysis, O.S. and S.F.E.; investigation, O.S. and S.F.E.; data curation, N.N., O.S., and S.F.E.; writing —original draft preparation, O.S. and S.F.E.; writing-review and editing, N.N. and Y.D.; visualization, Y.D.; supervision, N.N.; project administration, N.N.; funding acquisition, N.N. All authors have read and agreed to the published version of the manuscript.

Funding: This research was written within the research project "Methods for Transparent Energy Planning of Urban Building Stocks- ExPOSe", which was funded by the Research Council of Norway, grant number 268248.

Acknowledgments: The authors gratefully acknowledge the support from Department of Energy and Process Engineering of NTNU to the work package "Urban Building Stock Policies Developmentfrom Large to Small Scale" within ExPOSe research project. 
Conflicts of Interest: The authors declare no conflict of interest. The funders had no role in the design of the study; in the collection, analyses, or interpretation of data; in the writing of the manuscript; or in the decision to publish the results.

\section{References}

1. Yoshino, H.; Hong, T.; Nord, N. IEA EBC annex 53: Total energy use in buildings-Analysis and evaluation methods. Energy Build. 2017, 152, 124-136. [CrossRef]

2. Chen, Y.; Hong, T.; Piette, M.A. Automatic generation and simulation of urban building energy models based on city datasets for city-scale building retrofit analysis. Appl. Energy 2017, 205, 323-335. [CrossRef]

3. Robinson, D. Integrated resource flow modelling of the urban built environment. Build. Perform. Simul. Design Oper. 2019, 659-695. [CrossRef]

4. Dominković, D.F.; Junker, R.G.; Lindberg, K.B.; Madsen, H. Implementing flexibility into energy planning models: Soft-linking of a high-level energy planning model and a short-term operational model. Appl. Energy 2020, 260, 114292. [CrossRef]

5. Crawley, D.B. Building Simulation for Policy Support; Routledge: Milton Park, Oxon, UK, 2012; pp. $493-504$.

6. D'Oca, S.; Corgnati, S.; Hong, T. Data Mining of Occupant Behavior in Office Buildings. Energy Procedia 2015, 78, 585-590. [CrossRef]

7. Kavgic, M.; Summerfield, A.; Mumovic, D.; Stevanovic, Z. Application of a Monte Carlo model to predict space heating energy use of Belgrade's housing stock. J. Build. Perform. Simul. 2014, 8, 375-390. [CrossRef]

8. Fonseca, J.A.; Nguyen, T.-A.; Schlueter, A.; Marechal, F. City Energy Analyst (CEA): Integrated framework for analysis and optimization of building energy systems in neighborhoods and city districts. Energy Build. 2016, 113, 202-226. [CrossRef]

9. Abubakar, I.R.; Dano, U.L. Sustainable urban planning strategies for mitigating climate change in Saudi Arabia. Environ. Dev. Sustain. 2019, 22, 5129-5152. [CrossRef]

10. Tereshchenko, T.; Nord, N. Energy planning of district heating for future building stock based on renewable energies and increasing supply flexibility. Energy 2016, 112, 1227-1244. [CrossRef]

11. Lund, H. Renewable Energy Systems, 2nd ed.; Elsevier: Amsterdam, The Netherlands, 2014. Available online: https://www. elsevier.com/books/renewable-energy-systems/lund/978-0-12-410423-5 (accessed on 28 January 2021).

12. Statistics Norway. Energy and Manufacturing. Available online: https://www.ssb.no/en/energi-og-industri (accessed on 28 January 2021).

13. Skrautvol, O.; Eliassen, S.F. Energiveier for Framtidige Bygningsområder. 2016. Available online: https://ntnuopen.ntnu.no/ ntnu-xmlui/handle/11250/2408932 (accessed on 28 January 2021).

14. Tereshchenko, T.; Nord, N. Uncertainty of the allocation factors of heat and electricity production of combined cycle power plant. Appl. Therm. Eng. 2015, 76, 410-422. [CrossRef]

15. EQUA. IDA ICE-Simulation Software I EQUA. Available online: https://www.equa.se/en/ida-ice (accessed on 28 January 2021$)$.

16. Enova. Manual for Enøk Normtall; Enova: Chicago, IL, USA, 2004. Available online: https://www.enova.no (accessed on 28 January 2021).

17. NS 3031:2014. Available online: https://www.standard.no/no/Nettbutikk/produktkatalogen/Produktpresentasjon/ ?ProductID=702386 (accessed on 28 January 2021).

18. ISO. ISO 13790:2008. Available online: https://www.iso.org/cms/render/live/en/sites/isoorg/contents/data/standard/04/1 9/41974.html (accessed on 28 January 2021).

19. SINTEF. ENØK i Bygninger: Effektiv Energibruk-Nasjonalbiblioteket. Available online: https://www.nb.no/nbsok/nb/b2d4 6004b547a3f561e5d669d816ea05?lang=no (accessed on 28 January 2021).

20. Direktoratet for byggkvalitet. Regulations on Technical Requirements for Construction Works. Available online: https:/ / dibk.no/ regelverk/Building-Regulations-in-English/ (accessed on 28 January 2021).

21. NS 3700:2013. Available online: https:/ / www.standard.no/nettbutikk/produktkatalogen/produktpresentasjon/?ProductID=63 6902 (accessed on 28 January 2021).

22. NS 3720:2018. Available online: https://www.standard.no/no/Nettbutikk/produktkatalogen/Produktpresentasjon/ ?ProductID=992162 (accessed on 28 January 2021).

23. Dou, Y.; Okuoka, K.; Fujii, M.; Tanikawa, H.; Fujita, T.; Togawa, T.; Dong, L. Proliferation of district heating using local energy resources through strategic building-stock management: A case study in Fukushima, Japan. Front. Energy 2018, 12, 411-425. [CrossRef]

24. Aksözen, M.; Hassler, U.; Kohler, N. Reconstitution of the dynamics of an urban building stock. Build. Res. Inf. 2016, 45, 239-258. [CrossRef]

25. Vásquez, F.; Løvik, A.N.; Sandberg, N.H.; Müller, D.B. Dynamic type-cohort-time approach for the analysis of energy reductions strategies in the building stock. Energy Build. 2016, 111, 37-55. [CrossRef]

26. Nord, N.; Nielsen, E.K.L.; Kauko, H.; Tereshchenko, T. Challenges and potentials for low-temperature district heating implementation in Norway. Energy 2018, 151, 889-902. [CrossRef]

27. Sandberg, N.H.; Sartori, I.; Brattebø, H. Sensitivity analysis in long-term dynamic building stock modeling-Exploring the importance of uncertainty of input parameters in Norwegian segmented dwelling stock model. Energy Build. 2014, 85, 136-144. [CrossRef] 
28. Albelwi, N. Assessing the Environmental Sustainability of the Urban Ecosystem Using Material Flow Analysis: The Case of Riyadh Housing Stock. Ph.D. Thesis, Cardiff University, Cardiff, UK, 2019.

29. Statistics Norway. Population. Available online: https://www.ssb.no/en/befolkning (accessed on 28 January 2021).

30. Lavenergiutvalget. Lavenergiutvalget-Energieffektivisering. 25 June 2009. Available online: https:/ /www.regjeringen.no/no/ dokumenter/lavenergiutvalget---energieffektiviserin/id570063/ (accessed on 28 January 2021).

31. Frederiksen, S.; Werner, S. District Heating and Cooling; Studentlitteratur AB: Lund, Sweden, 2013.

32. Norsk Eenergi. Klimaregnskap for fjernvarme. Available online: http://www.fjernvarme.no/uploads/Rapport_Klimaregnskap\% 20for\%20fjernvarme_2.pdf (accessed on 28 January 2021).

33. NVE. Varedeklarasjon for Strømleverandører-NVE. Available online: https:/ / www.nve.no/energiforsyning/opprinnelsesgarantier/ varedeklarasjon-for-stromleverandorer/?ref=mainmenu (accessed on 28 January 2021).

34. Taner, T.; Sivrioglu, M. Energy-exergy analysis and optimisation of a model sugar factory in Turkey. Energy 2015, 93, 641-654. [CrossRef]

35. Taner, T.; Sivrioglu, M. A techno-economic \& cost analysis of a turbine power plant: A case study for sugar plant. Renew. Sustain. Energy Rev. 2017, 78, 722-730. [CrossRef]

36. Allard, S.; Mima, S.; Debusschere, V.; Quoc, T.T.; Criqui, P.; Hadjsaid, N. European transmission grid expansion as a flexibility option in a scenario of large scale variable renewable energies integration. Energy Econ. 2020, 87, 104733. [CrossRef]

37. Kauko, H.; Kvalsvik, K.H.; Rohde, D.; Nord, N.; Utne, A. Dynamic modeling of local district heating grids with prosumers: A case study for Norway. Energy 2018, 151, 261-271. [CrossRef]

38. Nord, N.; Schmidt, D.; Kallert, A.M.D. Necessary Measures to Include more Distributed Renewable Energy Sources into District Heating System. Energy Procedia 2017, 116, 48-57. [CrossRef]

39. Zhang, C.J.; Wang, L.G.; Wu, L.N.; Liu, T.; Lu, Q.; Dong, C.Q. Discussion of Energy Consumption Analysis Method on Energy System. Appl. Mech. Mater. 2011, 1578-1581. [CrossRef]

40. Hobley, A. Will gas be gone in the United Kingdom (UK) by 2050? An impact assessment of urban heat decarbonisation and low emission vehicle uptake on future UK energy system scenarios. Renew. Energy 2019, 142, 695-705. [CrossRef]

41. Bogdanov, D.; Breyer, C. Eurasian Super Grid for 100\% Renewable Energy Power Supply: Generation and Storage Technologies in the Cost Optimal Mix. In Proceedings of the ISES Solar World Congress 2015, Daegu, Korea, 8-12 November 2015; pp. 1-15. [CrossRef]

42. Taner, T.; Sivrioğlu, M.; Topal, H.; Dalkılıç, A.S.; Wongwises, S. A model of energy management analysis, case study of a sugar factory in Turkey. Sadhana 2018, 43, 42. [CrossRef] 